\title{
EVALUASI PEMBELAJARAN MELALUI PENULISAN JURNAL REFLEKTIF BERBASIS PENILAIAN DIRI DI PBS. INDONESIA STKIP SILIWANGI
}

\author{
${ }^{1)}$ Diena San Fauziya, ${ }^{2)}$ Alfa Mitri Suhara \\ ${ }^{1,2)}$ Program Studi Pendidikan Bahasa dan Sastra Indonesia, STKIP Siliwangi
}

\begin{abstract}
ABSTRAK
Tes yang selama ini digunakan sebagai bentuk evaluasi sesungguhnya bukanlah satu-satunya bentuk evaluasi yang dapat dilakukan, melainkan banyak jenis lain yang dapat digunakan, di antaranya penulisan jurnal reflektif dan penilaian diri. Penelitian ini mencoba untuk merekam bagaimana respon dan hasil penilaian pembelajaran yang dilakukan melalui penulisan jurnal reflektif berbasis penilaian diri sebagai salah satu alternatif penilaian pembelajaran. Metode yang dilakukan untuk memecahkan masalah adalah deskriptif melalui survei dengan penyebaran angket dan praktik penilaian jurnal reflektif berbasis penilaian diri. Sampel yang diambil adalah para mahasiswa Program Studi Pendidikan Bahasa Indonesia. Dari data yang terkumpul diperoleh simpulan bahwa penulisan jurnal reflektif efektif digunakan dan menyenangkan karena responden dapat mengetahui potensi yang dimilikinya dan dapat meningkatkan keterampilan menulis. Selain itu, diketahui juga bahwa melalui jurnal reflektif berbasis penilaian diri, pembelajar dapat menuangkan keterpahamannya mengenai materi, mengaitkan materi dengan apa yang dialami oleh dirinya, mengetahui hal-hal yang menjadi kendala, serta merencanakan solusi untuk mengatasi kendala tersebut.
\end{abstract}

Kata Kunci: evaluasi, penilaian, pembelajaran, jurnal reflektif

\begin{abstract}
The test which has been used as a form of evaluation is actually not the only form of evaluation that can be done, but many other types that can be used, including journal writing and reflective self-assessment. This study tries to record how the responses and the assessment of learning is done through a reflective journal writing-based self-assessment as an alternative learning assessment. The method used to solve the problem is through a descriptive survey questionnaire and assessment practices reflective journal-based self-assessment. Samples taken are students Indonesian Education Studies Program. From the data collected be concluded that reflective journal writing effective use and fun because the respondents can know its potential and can enhance writing skills. In addition, note also that through reflective journalbased self-assessment, learners can pour keterpahamannya of matter, associate the material with what is experienced by himself, knowing the things that become obstacles, and to plan solutions to overcome these obstacles.
\end{abstract}

Keywords: evaluation, assessment, learning, reflective journals 


\section{A. PENDAHULUAN}

Evaluasi merupakan salah satu kegiatan yang penting dalam pembelajaran. Sesuai dengan konsep pembelajaran berdasarkan kurikulum, evaluasi merupakan sebuah kegiatan yang harus selalu ada dan dilaksanakan pada setiap proses pembelajaran. Tujuannya adalah untuk merefleksi dan mengetahui bagaimana keberhasilan proses pembelajaran yang telah dilakukan.

Dalam pembelajaran selama ini, para praktisi pendidikan, khususnya praktisi pembelajaran, lebih mengedepankan penilaian yang bersifat kuantitatif, yakni melalui pengukuran dan tes. Padahal, sesungguhnya evaluasi sangat bisa dilakukan dengan cara kualitatif melalui nontes. Banyak jenis non-tes yang dapat digunakan untuk menilai dan kemudian mengevaluasi pembelajaran, salah satunya adalah melalui penulisan jurnal reflektif.

Tim USAID PRIORITAS (2013:157) mengemukakan bahwa jurnal reflektif merupakan kumpulan catatan perenungan dan analisis tentang aktivitas serta rencana tindak lanjut untuk hal-hal yang ditemukan dalam perenungan tersebut. Dari pernyataan tersebut, sangat jelaslah tergambar bahwa jurnal reflektif merupakan suatu media yang dapat digunakan untuk mengevaluasi apa yang telah dilakukan, apa ketercapaiannya, apa kelemahannya, dan apa rencana selanjutnya untuk memperbaiki apa yang harus diperbaiki.

Dalam pembelajaran bahasa, khususnya di Program Studi PBS. Indonesia STKIP Siliwangi Bandung sebagai lingkungan penelitian ini akan dilaksanakan, jurnal reflektif ini diharapkan mampu menjadi sebuah media yang dapat meningkatkan kualitas proses pembelajaran. Selain untuk melakukan evaluasi mengenai proses, melalui penulisan jurnal reflektif ini sesungguhnya dosen dan mahasiswa dapat melatih keterampilan berbahasa. Seperti yang telah diketahui bersama, salah satu keterampilan berbahasa adalah menulis. Jadi, secara otomatis penulisan jurnal reflektif ini selain sebagai kegiatan evaluasi juga dapat dijadikan sarana pengembangan keterampilan menulis.

Sebagai bahan refleksi dalam mengukur kualitas proses pembelajaran bahasa, yang ditekankan dalam evaluasi melalui penulisan jurnal reflektif ini adalah penilaian diri. Evaluasi sebagai payung dari kegiatan penilaian merupakan proses menilai secara kualitatif untuk mengetahui kualitas pembelajaran. Yang paling penting dalam hal itu adalah bagaimana seseorang dapat menilai diri untuk kemajuan dirinya sendiri. Oleh karena itu, evaluasi pembelajaran melalui penulisan jurnal reflektif berbasis pada penilaian diri. Dengan demikian, proses evaluasi ini diharapkan dapat mampu memberikan cerminan atau refleksi diri untuk menilai kualitas diri dalam pembelajaran agar dapat mempertahankan yang sudah optimal dan meningkatkan yang kurang optimal agar menjadi lebih optimal.

Berdasarkan uraian di atas, maka terdapat tiga rumusan masalah yang diajukan dalam tulisan ini: pertama bagaimanakah proses penilaian pembelajaran di Program Studi PBS. Indonesia sebelum diterapkan penilaian pembelajaran melalui penulisan jurnal reflektif?; kedua, bagaimanakah proses penilaian pembelajaran melalui penulisan jurnal reflektif berbasis penilaian diri di Program Studi PBS. Indonesia?; ketiga bagaimana hasil penilaian pembelajaran melalui penulisan jurnal reflektif berbasis penilaian diri di Program Studi PBS. Indonesia?

\section{B. KAJIAN TEORI DAN METODE}

Menurut Arifin (2013:5), pada hakikatnya evaluasi adalah suatu proses yang sistematis dan berkelanjutan untuk menentukan kualitas (nilai atau arti) dari sesuatu, berdasarkan pertimbangan dan kriteria tertentu dalam rangka pembuatan keputusan. Senada dengan hal iu, Sanjaya (2013:241) juga merujuk pernyataan yang sama yang sebelumnya dikemukakan oleh Guba dan Lincoln, yakni bahwa evaluasi itu merupakan suatu proses 
memberikan pertimbangan mengenai nilai dan arti sesuatu yang dipertimbangkan.

Lebih lanjut, Sanjaya mengemukakan bahwa evaluasi merupakan proses yang sangat penting dalam kegiatan pendidikan formal. Menurutnya, evaluasi dapat menentukan efektivitas kinerja guru selama ini, sementara bagi pengembang kurikulum evaluasi dapat memberikan informasi untuk perbaikan kurikulum yang sedang berjalan.

Dalam proses pembelajaran, Sanjaya (2013:243) mengemukakan beberapa fungsi evaluasi, yakni (1) evaluasi merupakan alat yang penting sebagai umpan balik siswa; (2) evaluasi merupakan alat yang penting untuk mengetahui bagaimana ketercapaian siswa dalam menguasai tujuan yang telah ditentukan; (3) evaluasi dapat memberikan informasi untuk mengembangkan kurikulum; (4) evaluasi berguna bagi pengembang kurikulum khususnya dalam nenentukan kejelasan tujuan yang ingin dicapai; dan (5) evaluasi berfungsi sebagai umpan balik untuk semua pihak yang berkepentingan dengan pendidikan di sekolah.

Dari pernyataan di atas, jelaslah kiranya apa dan bagaimana itu evaluasi. Secara singkat, evaluasi dimaknai sebagai proses pengambilan keputusan mengenai kualitas pembelajaran yang telah dilakukan.

Sementara itu, jurnal reflektif diartikan USAID PRIORITAS (2013:157) sebagai kumpulan catatan perenungan dan analisis tentang aktivitas serta rencana tindak lanjut untuk hal-hal yang ditemukan dalam perenungan tersebut. Lebih lanjut, sumber yang sama menyatakan pentingnya menulis jurnal reflektif.

Kemampuan menulis jurnal reflektif dari sebuah aktivitas yang dilakukan, baik oleh dosen, guru, kepala sekolah, maupun pengawas merupakan keterampilan yang sangat penting untuk dikembangkan. Dengan berefleksimerenungkan dan menganalisis apa saja yang telah dilakukan serta pengaruhnya-akan dapat menemukan kelebihan dan kelemahan sebuah aktivitas (USAID PRIORITAS, 2013:157).

Pernyataan di atas tentu menjadi sebuah landasan penting dalam penulisan jurnal reflektif. Reflektif yang berkaitan erat dengan refleksi memberikan makna mendalam tentang bagaimana seseorang menilai diri, mengevaluasi diri, dan menganalisis apa yang sudah baik dan apa yang kurang baik. Bekal itulah yang kemudian menjadi cerminan bagi seseorang untuk meningkatkan upayanya demi mecapai tujuan yang diharapkan.

Jurnal reflektif bagi siswa/mahasiswa berisi hal-hal terkait jawaban dari pertanyaan berikut.

a. Apa saja yang telah kamu pahami? Apa yang telah bisa kamu lakukan dengan baik?

b. Seandainya kamu diminta melakukan lagi, kira-kira bagaimana kamu akan melakukannya? (pertanyaan diberikan setelah siswa melakukan sesuatu kinerja tertentu)

c. Hal apa yang masih membingungkan? Kira-kira mengapa kamu masih bisa bingung?

d. Apa yang perlu dilakukan untuk mengatasi kebingungan itu? Bantuan Apa yang kamu perlukan?

Lebih jauh dari itu, USAID PRIORITAS (2013:167-168) juga mengemukakan pentingnya menulis jurnal reflektif untuk siswa/mahasiswa, yakni bahwa kebiasaan menulis jurnal reflektif oleh siswa/mahasiswa atau juga dosen memiliki beberapa manfaat seperti berikut.

1) Dengan adanya tradisi menulis jurnal reflektif, siswa/mahasiswa akan terbiasa menuangkan pikiran dan perasaannya secara tertulis sesuai dengan proses yang dialami pada saat kegiatan pembelajaran.

2) Dengan membaca jurnal reflektif, siswa/mahasiswa, guru/dosen, bisa lebih memahami pikiran dan perasaan siswa 
tentang kegiatan pembelajaran yang diikutinya.

3) Dengan menulis jurnal reflektif, siswa/mahasiswa belajar mengevaluasi proses belajar yang sedang dialami.

Sekaitan dengan penilaian diri, Permendikbud Nomor 81A Tahun 2013 menyebutkan bahwa penilaian diri adalah suatu teknik penilaian di mana peserta didik diminta untuk menilai dirinya sendiri berkaitan dengan status, proses dan tingkat pencapaian kompetensi yang dipelajarainya. Penilaian diri ini merupakan salah satu teknik penilaian yang ditawarkan dalam implementasi kurikulu 2013.

Lebih lanjut, Permendikbud No 81A tahun 2013 menyatakan bahwa penilaian diri ini merupakan teknik penilaian yang dapat memberi dampak positif terhadap perkembangan kepribadian seseorang. Dicantumkan secara jelas dalam Permendikbud tersebut bahwa penilaian diri ini memberikan beberapa manfaat bagi peserta didik di dalam kelas, yakni (1) menumbuhkan rasa percaya diri peserta didik; (2) peserta didik dapat menyadari kekuatan dan kelemahan dirinya; (3) penilaian diri dapat mendorong, membiasakan, dan melatih peserta didik untuk berbuat jujur.

P4TK Bahasa (2009:17) mengemukakan bahwa teknik penilaian diri dapat digunakan untuk mengukur kompetensi kognitif, afektif, dan psikomotorik. Lebih lanjut diuraikan sebagai berikut.

a) Penilaian kompetensi kognitif di kelas, misalnya peserta didik diminta untuk menilai penguasaan pengetahuan dan keterampilan berpikirnya sebagai hasil belajar dari suatu mata pelajaran ertentu. Penilaian diri peserta didik didasarkan atas kriteria atau acuan yang telah disiapkan.

b) Penilaian kompetensi afektif, misalnya peserta didik dapat diminta untuk membuat tulisan yang memuat curahan perasaannya terhadap suatu objek tertentu. Selanjutnya, peserta didik diminta untuk melakukan penilaian berdasarkan kriteria atau acuan yang telah disiapkan.

c) Berkaitan dengan penilaian kompetensi psikomotorik, peserta didik dapat diminta untuk menilaian kecakapan atau keterampilan yang telah dikuasai berdasarkan kriteria atau acuan yang telah disiapkan.

Sesuai dengan teori di atas, penilaian diri memanglah harus menyangkut tiga ranah penilaian, yakni afektif, kognitif, dan psikomotorik. Dalam penelitian ini, ketiga ranah ini akan ternilai melalui jurnal reflektif. Yang menjadi landasan bukanlah kriteria atau acuan berupa nilai, melainkan berupa panduan pertanyaan. Hal ini disesuaikan dengan variabel penelitian, yakni penulisan jurnal reflektif. Dengan kata lain, penulisan jurnal reflektif untuk menilai diri dibimbing melalui pertanyaan-pertanyaan. Adapun pertanyaan untuk menilai ketiga ranah tersebut telah diuraikan dalam teori jurnal reflektif pada bagian sebelumnya.

Sebagai cara pemecahan masalah dan berdasarkan teori-teori landasan, metode yang digunakan dalam penelitian ini adalah penelitian deskriptif. Hal ini dilatarbelakangi oleh permasalah yang muncul memerlukan kajian kualitatif sebagai pemecahan masalahnya. Sanjaya (2013:59) mengemukakan bahwa metode penelitian deskriptif (descriptive research) adalah penelitian yang dilakukan untuk menggambarkan atau menjelaskan secara sistematis, faktual dan akurat mengenai fakta dan sifat populasi tertentu.

Populasi penelitian adalah mahasiswa Program Studi Pendidikan Bahasa Indonesia STKIP Siliwangi Bandung. Namun, dari populasi tersebut diambil sampel satu kelas saja secara random.

Instrumen yang digunakan untuk menjaring data berupa lembar angket dan blangko jurnal reflektif dengan panduan pertanyaan. 


\section{HASIL DAN PEMBAHASAN}

Berdasarkan hasil perhitungan angket mengenai penilaian proses pembelajaran bahasa di Program Studi PBS. Bahasa Indonesia sebelum diterapkan evaluasi pembelajaran melalui penulisan jurnal reflektif berbasis penilaian diri diketahui hampir $90 \%$ responden sepakat selama ini penilaian dalam perkuliahan tidak hanya dilakukan di akhir semester, berdasarkan data selanjutnya, diperoleh hasil bahwa penilaian juga tidak hanya dilakukan dengan pada saat tengah semester dan akhir semester saja. Artinya, ada moment-moment lain yang dijadikan sebagai bahan penilaian. Data selanjutnya menunjukkan responden memberikan keterangan yang relevan bahwa penilaian tidak hanya dilakukan melalui tes (ujian).

Di samping itu, semua sepakat atau 100\% responden menilai bahwa selama ini penilaian dilakukan hanya oleh dosen. Berdasarkan hal itu, mereka sepakat bahwa melalui penilaian yang selama ini dilakukan mereka tidak bias merefleksi diri dan mereka juga sepakat bahwa dengan demikian mereka tidak bias memperbaiki diri. Respon responden terhadap penilaian yang selama ini terjadi cukup bagus. Artinya, mereka tidak mempermasalahkan bagaimana cara penilaian yang selama ini terjadi.

Selanjutnya, untuk menjawab rumusan masalah ke dua, diperoleh hasil bahwa hampir $100 \%$ responden mengatakan penilaian diri lebih efektif daripada tes. Hal tersebut terbukti dengan jawaban ya sebanyak 26 dan tidak 1 orang. Hampir 90\% responden juga mengemukakan bahwa penilaian diri lebih menyenangkan daripada tes. Data selanjutnya menunjukkan bahwa penilaian diri membuat mereka menyadari potensi diri sehingga semua sepakat melalui penilaian diri mereka dapat memperbaiki diri.

Semua responden juga mengemukakan bahwa penulisan jurnal reflektif menyenangkan dan hampir $80 \%$ responden mengaku bahwa jurnal reflektif melatih keterampilan menulis. Data terakhir menunjukkan bahwa hampir $80 \%$ responden setuju penulisan jurnal reflektif harus terus dibiasakan, meskipun ada hampir $30 \%$ mengatakan penulisan jurnal reflektif menghambat proses pembelajaran. Bagian terakhir ditengarai karena ada beberapa mahasiswa yang agak kesulitan jika melakukan proses menulis di dalam kelas.

Rumusan masalah ketiga terjawab dengan hasil-hasil yang menunjukkan bahwa jurnal reflektif dapat memotret penilaian diri melalui empat aspek, yakni keterpahaman terhadap materi yang telah dibahas, hal-hal yang telah dapat dilakukan, hal-hal yang masih dianggap bingung, serta solusi untuk mengatasi kebingungan. Berdasarkan perhitungan dari hasil proses pembelajaran bahasa setelah diterapkan penilaian pembelajaran melalui penulisan jurnal reflektif berbasis penilaian diri diketahui penilaian pada aspek keterpahaman persentase yang diperoleh pada pertemuan pertama sebesar $100 \%$ mampu menguraikan keterpahaman mereka terhadap materi perkuliahan dan 0\% tidak mampu menguraikan. Pertemuaan ke dua sebesar 92,5\% menjawab mampu menguraikan dan $3,7 \%$ tidak mampu menguraikan. Pertemuan ketiga sebesar $100 \%$ mmpu menguraikan dan $0 \%$ tidak mampu menguraikan. Artinya, pada aspek keterpahaman sampel dapat memahami materi perkuliahan dengan baik. Hal ini dapat dilihat dari persentase yang diperoleh.

Aspek penilaian kedua, yaitu hal yang sudah dilakukan persentase yang diperoleh pada pertemuan pertama sebesar $51,8 \%$ telah mampu mengemukakan hal yang sudah dilakukan sekaitan dengan materi perkuliahan, $48,1 \%$ belum mampu mengemukakan hal yang sudah dilakukan sesuai dengan materi perkuliahan. Pertemuaan ke dua sebesar 33,3\% mampu mengemukakan dan $62,9 \%$ belum mampu mengemukakan. Pertemuan ke tiga sebesar $48,1 \%$ mengemukakan dan $51,8 \%$ belum mampu mengemukakan hal yang sudah dilakukan. Artinya, sampel memiliki sifat inisiatif yang cukup baik. Hal ini terlihat dari persentase yang diperoleh dari hasil perhitungan di atas cenderung stabil. 
Aspek penilaian ke tiga, yaitu hal yang membingungkan persentase yang diperoleh pada pertemuan pertama sebesar 33,3\% mengemukakan kebingungan yang ditemukan sementara $66,6 \%$ tidak mengemukakan hal yang membingungkan. Pertemuaan ke dua sebesar $44,4 \%$ mengemukakan dan $51,8 \%$ tidak mengemukakan. Pertemuan ke tiga sebesar 66,6\% mengemukakan dan 33,3\% tidak mengemukakan. Artinya, dalam pembelajaran sampel banyak yang belum memahami secara benar mengenai materi perkuliahan yang disampaikan oleh dosen.

Aspek penilaian ke empat, yaitu solusi mengatasi kebingungan persentase yang diperoleh pada pertemuan ke satu sebesar 22,2\% mampu merencanakan solusi, 77,7\% tidak merencanakan solusi. Pertemuan ke dua sebesar $37 \%$ merencanakan solusi dan 59,2\% tidak merencanakan solusi. Pertemuan ke tiga sebesar $55,5 \%$ mengemukakan solusi dan 44,4\% tidak mengemukakan solusi. Artinya penilaian jurnal reflektif dapat membantu untuk mengatasi kebingungan yang dihadapi sampel dalam memahami dengan benar mata kuliah yang diberikan, meskipun tidak terjadi pada semua responden.

\section{KESIMPULAN}

Hasil penelitian dan pembahasan pada bab sebelumnya menunjukan bahwa secara umum dapat disimpulkan evaluasi pembelajaran melalui penulisan jurnal reflektif berbasis penilaian diri dalam pembelajaran bahasa dapat meningkatkan kualitas pembelajaran mahasiswa STKIP Siliwangi Bandung. Jurnal reflektif merupakan hasil catatan dan analisis yang harus memiliki siklus reflektif sebagai bahan pertimbangan atau pengambilan keputusan (tindak lanjut) untuk perbaikan kegiatan pembelajaran selanjutnya. Secara khusus beberapa hal yang dapat disimpulkan sesuai dengan rumusan penelitian sebagai berikut.

Pertama, berdasarkan hasil pengolahan data pada penilaian proses pembelajaran bahasa sebelum diterapkan evaluasi pembelajaran melalui jurnal reflektif berbasis penilaian diri yang diketahui bahwa selama ini penilaian yang telah dilakukan tidak hanya dilakukan saat UTS dan UAS. Penilaian juga juga tidak selalu dilakukan hanya dengan tes. Jawaban mengenai tes ini beragam dan hampir berimbang. Hal ini diyakini terjadi karena setiap dosen memiliki gaya penilaian yang berbeda dan penilaian hanya dilakukan oleh dosen saja.

Kedua, berdasarkan pengolahan data pada proses pembelajaran melalui penulisan jurnal reflektif berbasis penilaian diketahui bahwa penilaian diri lebih efektif, menyenangkan, responden dapat mengetahui potensi yang dimilikinya, dan dapat meningkatkan keterampilan menulis.

Ketiga, hasil penilaian pembelajaran melalui penulisan jurnal reflektif berbasis penilaian diri yang dilakukan sebanyak tiga kali refleksi menunjukan adanya kemampuan-kemampuan yang meningkat dari segi pengukuran keterpahaman dan penilaian atas kemampuan diri sendiri terkait pembelajaran. Hal ini terbukti dari rata-rata keseluruhan responden dari tiga pertemuan dapat menguraikan pemahaman terkait materi perkuliahan secara benar. Responden juga mampu menilai diri dengan mengaitkan materi dengan apa yang ia alami serta menceritakan masalah yang dihadapi beserta solusinya.

Untuk ke depannya, pelaksanaan penilaian pembelajaran dengan jurnal reflektif berbasis penilaian diri akan lebih baik jika diimbangi dengan penggunaan jenis penilaian lainnya sehingga evaluasi pembelajaran lebih terukur.

\section{E. DAFTAR PUSTAKA}

Arikunto, S. 2013. Dasar-dasar Evaluasi Pendidikan: Edisi 2. Bandung: Bumi Aksara.

P4TK Bahasa. 2009. Penilaian. Jakarta: Direktorat Jenderal Peningkatan Mutu Pendidik dan Tenaga Kependidikan, Departemen Pendidikan Nasional. 
Permendikbud Nomor 81A Tahun 2013 tentang Implementasi Kurikulum

Sanjaya, W. 2013. Perencanaan dan Desain Sistem Pembelajaran. Jakarta: Kencana Prenada Media Group.

USAID PRIORITAS. 2013. Praktik yang Baik dalam Pembelajaran. Jakarta: tidak diterbitkan.

UU No. 20 Tahun 2003 tentang Sistem Pendidikan Nasional

Wahyuni, S. \& Abd. Syukur Ibrahim. 2013. Perencanaan Pembelajaran Bahasa Berkarakter. 2012. Bandung: Refika Aditama. 